\title{
Non-random association between alleles detected at D4S95 and D4S98 and the Huntington's disease gene
}

\author{
J THEILMANN*, S KANANI*, R SHIANG + , C ROBBINS*, O QUARRELL*, \\ M HUGGINS*, A HEDRICK*, B WEBER*, C COLLINS*, J J WASMUTH ${ }^{*}$, \\ K H BUETOW $\$$, J C MURRAY $\dagger$, AND M R HAYDEN* \\ From * the Department of Medical Genetics, University of British Columbia, Vancouver, Canada V6T 2B5; \\ †Department of Pediatrics, University of Iowa; $¥$ Department of Biological Chemistry, University of \\ California, Irvine; and §Division of Population Science, Fox Chase Cancer Centre, Philadelphia, USA.
}

SUMmARY Analysis of many families with linked DNA markers has provided support for the Huntington's disease (HD) gene being close to the telomere on the short arm of chromosome 4. However, analysis of recombination events in particular families has provided conflicting results about the precise location of the HD gene relative to these closely linked DNA markers. Here we report an investigation of linkage disequilibrium between six DNA markers and the HD gene in 75 separate families of varied ancestry. We show significant non-random association between alleles detected at D4S95 and D4S98 and the mutant gene. These data suggest that it may be possible to construct high and low risk haplotypes, which may be helpful in DNA analysis and genetic counselling for HD, and represent independent evidence that the gene for HD is centromeric to more distally located DNA markers such as D4S90. This information may be helpful in defining a strategy to clone the gene for HD based on its location in the human genome.

Directed attempts to clone the gene for Huntington's disease (HD) depend on an accurate knowledge of its location in the human genome. Over the last few years different DNA markers closely linked to the HD gene have been identified..$^{1-4}$ Analysis of many HD families with these markers has provided evidence that the gene causing HD lies close to the telomere of the short arm of chromosome $4 .{ }^{56}$ Currently, attempts are being made to define physically the minimal genomic fragment which contains the HD gene. Towards this goal and in an effort to identify clearly a flanking marker for the gene, recent efforts have been directed towards cloning the telomere of chromosome $4 \mathrm{p} .^{7}$

Analysis of families in which recombination between a closely linked DNA marker and the mutant gene has occurred can be extremely helpful in determining the order of the mutant gene relative to these linked DNA markers. We recently reported evidence suggesting the gene for HD was telomeric to the most distal marker $D 4 S 90^{8}$ based on an analysis of a recombinant in one large family. More recently, contradictory evidence has been presented. MacDonald et al ${ }^{9}$ have shown by analysis of

Received for publication 3 August 1989.

Accepted for publication 7 August 1989 recombinants in three families that the gene for HD may be flanked by the most distal markers in one family while analysis of two others favours a more telomeric location for the gene.

How can these apparent contradictions be resolved? While analysis of recombination events in selected families is useful in providing evidence in favour of a certain locus order, such studies may also be misinterpreted. One source of error in such analyses may include misdiagnosis of the disease in a crucial family member. In addition, the simplest interpretation of the data is to assume a single recombination event. However, in the absence of a clearly defined distal marker, double recombination events cannot be excluded. This may be particularly relevant as one uses DNA markers close to the telomere where enhanced recombination has already been postulated to occur. ${ }^{10}$ Additional independent sources of evidence in favour of a particular locus order relative to the HD gene are needed.

Linkage disequilibrium shown by a non-random association between an allele at one locus with the mutant gene would provide strong evidence that two loci are physically in close proximity. Here we report on the assessment of linkage disequilibrium between six DNA markers [D4S62 (P8), D4S10 
(G8), D4S95 (674), D4S98 (731), D4S96 (678), and D4S141 (2R3)] and the HD gene. We show that the gene for $\mathrm{HD}$ is in significant linkage disequilibrium with $D 4 S 95$ and $D 4 S 98$. This provides independent evidence that the gene for $\mathrm{HD}$ is proximal to $D 4 S 90$ and distal to D4S10. The most distally located DNA markers including $D 4 S 90$ are therefore likely to flank the gene for HD.

\section{Materials and methods}

\section{FAMILIES}

A total of 75 unrelated families with a documented history of HD was used in the analysis. All of these families were part of the Canadian Predictive Testing programme for HD. The ancestry of the families was determined during interviews with appropriate family members and is presented in table 1 . For controls the alleles in unrelated family members and the alleles segregating with the non-HD chromosome in affected persons were used. In all instances, the ancestry of the family members was assumed to be similar to that of the affected persons. Haplotypes for HD and marker restriction fragment length polymorphisms (RFLPs) were constructed using family studies where phase with HD was unequivocal.

\section{DNA ANALYSIS}

A total of 495 persons, 148 affected and 347

TABLE 1 Ancestries of affected persons in 75 separate families with $H D$.

\begin{tabular}{lc}
\hline & No \\
\hline United Kingdom & 21 \\
England & 6 \\
Ireland & 10 \\
Scotland & 0 \\
Wales & 4 \\
British (exact ancestry unknown) & 41 \\
Total & \\
Non-United Kingdom & 1 \\
Egypt & 4 \\
French Canadian & 5 \\
Germany & 2 \\
Holland & 1 \\
Pennsylvania Dutch & 1 \\
Hungary & 2 \\
Indian (Asian) & 1 \\
Metis (North American Indian) & 1 \\
Italy & 1 \\
Mennonite Dutch & 2 \\
Mennonite Russian & 2 \\
Norway & 1 \\
Romania & 2 \\
Russia & 1 \\
Sweden & 27 \\
Grand total & 7 \\
Ancestry unknown & 75 \\
Grand total & \\
\hline & \\
& \\
\hline
\end{tabular}

unaffected, from these 75 families was included in this analysis. DNA was extracted from leucocytes of each person and digested with restriction enzymes HincII, EcoRI, BglI, HindIII, AccI, TaqI, MboI, SstI, and MspI. Electrophoresis, transfer, and hybridisation conditions were performed as described previously. ${ }^{11-13}$ Ten polymorphisms detected by six DNA probes $D 4 S 62, D 4 S 10, D 4 S 95, D 4 S 98$, D4S96, and D4S141 were examined. A HincII polymorphism was detected by $D 4 S 62,{ }^{2}$ EcoRI, BglI, and HindIII polymorphisms recognised by $D 4 S 10,{ }^{1}$ AccI, TaqI, and MboI polymorphisms by $D 4 S 95,{ }^{3}$ a SstI polymorphism by $D 4 S 98,{ }^{14}$ and an $M s p I$ polymorphism by $D 4 S 96 .{ }^{14}$ Two polymorphisms are detected by $A c c I{ }^{3}$ The $A c c$ I polymorphism assessed in this analysis was the result of a single site variation and resulted in fragments of 6.8 and/or $1.5 \mathrm{~kb}$. D4S141 was isolated from the same cosmid as recognised by $D 4 S 90 .{ }^{15} \mathrm{~A}$ frequent HindIII polymorphism was used in this analysis.

The order of these DNA markers has been previously established as $D 4 S 62-D 4 S 10-D 4 S 95-D 4 S 98$ D4S96-D4S90-telomere. ${ }^{5689}$ A diagramatic map with approximate genetic distances between these DNA markers is shown in fig 1 . By convention, for single site variation polymorphisms, the larger band is termed A and the smaller band B (fig 2).

\section{STATISTICAL ANALYSIS}

Non-random association was evaluated by $\chi^{2}$ analysis of allelic counts for locus pairs. Significant association for biallelic pairs was determined by Fisher's exact probability test (one tailed). The linkage disequilibrium metric, $r$, was used to measure the magnitude of non-random association where $r=\left(g-p_{1} p_{2}\right)$ $\left(p_{1} q_{1} p_{2} q_{2}\right)^{1 / 2}$ and $p j$ and $q j$ are the frequencies of the alternative alleles at site $j$, and $g$ is the observed frequency of the $p_{1} p_{2}$ haplotype.

\section{Results}

The non-HD chromosome allelic frequencies for the 10 polymorphisms assessed are in general agreement with past studies ${ }^{1-4}$ and are shown in table 2 . The frequencies of the alleles for the HD chromosomes are similar to their unrelated family member

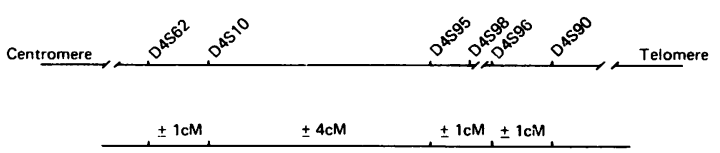

FIG 1 A diagramatic map showing approximate genetic distances between DNA markers used in this study. (Based on data presented in references $5,6,8$, and 9). 
TABLE 2 Allele frequencies and percentages for RFLPs on HD and non-HD chromosomes.

\begin{tabular}{|c|c|c|c|c|c|c|c|}
\hline & & \multicolumn{2}{|c|}{$H D$ chromosomes } & \multicolumn{2}{|c|}{ Non-HD chromosomes } & \multirow[t]{2}{*}{$r$} & \multirow[t]{2}{*}{$p$ value } \\
\hline & & No & $\%$ & No & $\%$ & & \\
\hline $\begin{array}{l}\text { D4S62 (P8) } \\
\text { (HincII) }\end{array}$ & $\begin{array}{l}\text { A } \\
\text { B } \\
\text { C } \\
\text { D } \\
\text { Total }\end{array}$ & $\begin{array}{r}25 \\
9 \\
6 \\
0 \\
40\end{array}$ & $\begin{array}{r}62.5 \\
22.5 \\
15 \cdot 0 \\
\\
100 \cdot 0\end{array}$ & $\begin{array}{r}115 \\
30 \\
14 \\
1 \\
160\end{array}$ & $\begin{array}{r}71 \cdot 9 \\
18 \cdot 8 \\
8.7 \\
0 \cdot 6 \\
100 \cdot 0\end{array}$ & 0.07 & NS \\
\hline $\begin{array}{l}D 4 S 10 \text { (G8) } \\
(\text { EcoRI) }\end{array}$ & $\begin{array}{l}\text { A } \\
\text { B } \\
\text { Total }\end{array}$ & $\begin{array}{l}17 \\
21 \\
38\end{array}$ & $\begin{array}{r}44 \cdot 7 \\
55 \cdot 3 \\
100 \cdot 0\end{array}$ & $\begin{array}{r}73 \\
76 \\
149\end{array}$ & $\begin{array}{r}49 \cdot 0 \\
51 \cdot 0 \\
100 \cdot 0\end{array}$ & -0.03 & NS \\
\hline $\begin{array}{l}\text { D4S10 (G8) } \\
(B g I I)\end{array}$ & $\begin{array}{l}\text { A } \\
\text { B } \\
\text { Total }\end{array}$ & $\begin{array}{l}18 \\
12 \\
30\end{array}$ & $\begin{array}{r}60 \cdot 0 \\
40 \cdot 0 \\
100 \cdot 0\end{array}$ & $\begin{array}{r}93 \\
49 \\
142\end{array}$ & $\begin{array}{r}65 \cdot 5 \\
34 \cdot 5 \\
100 \cdot 0\end{array}$ & -0.04 & NS \\
\hline $\begin{array}{l}\text { D4S10 (G8) } \\
\text { (HindIII) }\end{array}$ & $\begin{array}{l}\text { A } \\
\text { B } \\
\text { C } \\
\text { D } \\
\text { Total }\end{array}$ & $\begin{array}{r}24 \\
1 \\
3 \\
0 \\
28\end{array}$ & $\begin{array}{r}85 \cdot 7 \\
3.6 \\
10 \cdot 7 \\
\\
100 \cdot 0\end{array}$ & $\begin{array}{r}103 \\
13 \\
24 \\
3 \\
143\end{array}$ & $\begin{array}{r}72 \cdot 0 \\
9.1 \\
16 \cdot 8 \\
2.1 \\
100 \cdot 0\end{array}$ & $0 \cdot 08$ & NS \\
\hline $\begin{array}{l}\text { D4S95 (674) } \\
\text { (TaqI) }\end{array}$ & $\begin{array}{l}\text { A } \\
\text { B } \\
\text { Total }\end{array}$ & $\begin{array}{l}15 \\
40 \\
55\end{array}$ & $\begin{array}{r}27 \cdot 3 \\
72 \cdot 7 \\
100 \cdot 0\end{array}$ & $\begin{array}{r}76 \\
169 \\
245\end{array}$ & $\begin{array}{r}31 \cdot 0 \\
69 \cdot 0 \\
100 \cdot 0\end{array}$ & -0.03 & $0 \cdot 35$ \\
\hline $\begin{array}{l}\text { D4S95 (674) } \\
(\text { AccI) }\end{array}$ & $\begin{array}{l}\text { A } \\
\text { B } \\
\text { Total }\end{array}$ & $\begin{array}{l}54 \\
13 \\
67\end{array}$ & $\begin{array}{r}80 \cdot 6 \\
19 \cdot 4 \\
100 \cdot 0\end{array}$ & $\begin{array}{l}175 \\
100 \\
275\end{array}$ & $\begin{array}{r}63 \cdot 6 \\
36 \cdot 4 \\
100 \cdot 0\end{array}$ & 0.14 & 0.005 \\
\hline $\begin{array}{l}\text { D4S95 (674) } \\
\text { (MboI) }\end{array}$ & $\begin{array}{l}\text { A } \\
\text { B } \\
\text { Total }\end{array}$ & $\begin{array}{l}39 \\
12 \\
51\end{array}$ & $\begin{array}{r}76 \cdot 5 \\
23 \cdot 5 \\
100 \cdot 0\end{array}$ & $\begin{array}{r}107 \\
81 \\
188\end{array}$ & $\begin{array}{r}56 \cdot 9 \\
43 \cdot 1 \\
100 \cdot 0\end{array}$ & $0 \cdot 16$ & 0.007 \\
\hline $\begin{array}{l}\text { D4S98 (731) } \\
\text { (SstI) }\end{array}$ & $\begin{array}{l}\text { A } \\
\text { B } \\
\text { Total }\end{array}$ & $\begin{array}{r}6 \\
18 \\
24\end{array}$ & $\begin{array}{r}25 \cdot 0 \\
75 \cdot 0 \\
100 \cdot 0\end{array}$ & $\begin{array}{r}7 \\
85 \\
92\end{array}$ & $\begin{array}{r}7.6 \\
92 \cdot 4 \\
100 \cdot 0\end{array}$ & 0.22 & 0.026 \\
\hline $\begin{array}{l}\text { D4S96 (678) } \\
(M s p I)\end{array}$ & $\begin{array}{l}\text { A } \\
\text { B } \\
\text { Total }\end{array}$ & $\begin{array}{l}27 \\
21 \\
48\end{array}$ & $\begin{array}{r}56 \cdot 3 \\
43 \cdot 7 \\
100 \cdot 0\end{array}$ & $\begin{array}{r}128 \\
86 \\
214\end{array}$ & $\begin{array}{r}59 \cdot 8 \\
40 \cdot 2 \\
100 \cdot 0\end{array}$ & $-0 \cdot 03$ & NS \\
\hline $\begin{array}{l}\text { D4S14I (2R3) } \\
\text { (HindIII) }\end{array}$ & $\begin{array}{l}\text { A } \\
\text { B } \\
\text { Total }\end{array}$ & $\begin{array}{r}5 \\
17 \\
22\end{array}$ & $\begin{array}{r}22 \cdot 7 \\
77 \cdot 3 \\
100 \cdot 0\end{array}$ & $\begin{array}{l}28 \\
43 \\
71\end{array}$ & $\begin{array}{r}39 \cdot 4 \\
60 \cdot 6 \\
100 \cdot 0\end{array}$ & $-0 \cdot 15$ & NS \\
\hline
\end{tabular}

NS=not significant at $p \leqq 0 \cdot 05$.

TABLE 3 AccI and Mbol alleles of HD and non-HD chromosomes by ancestry.

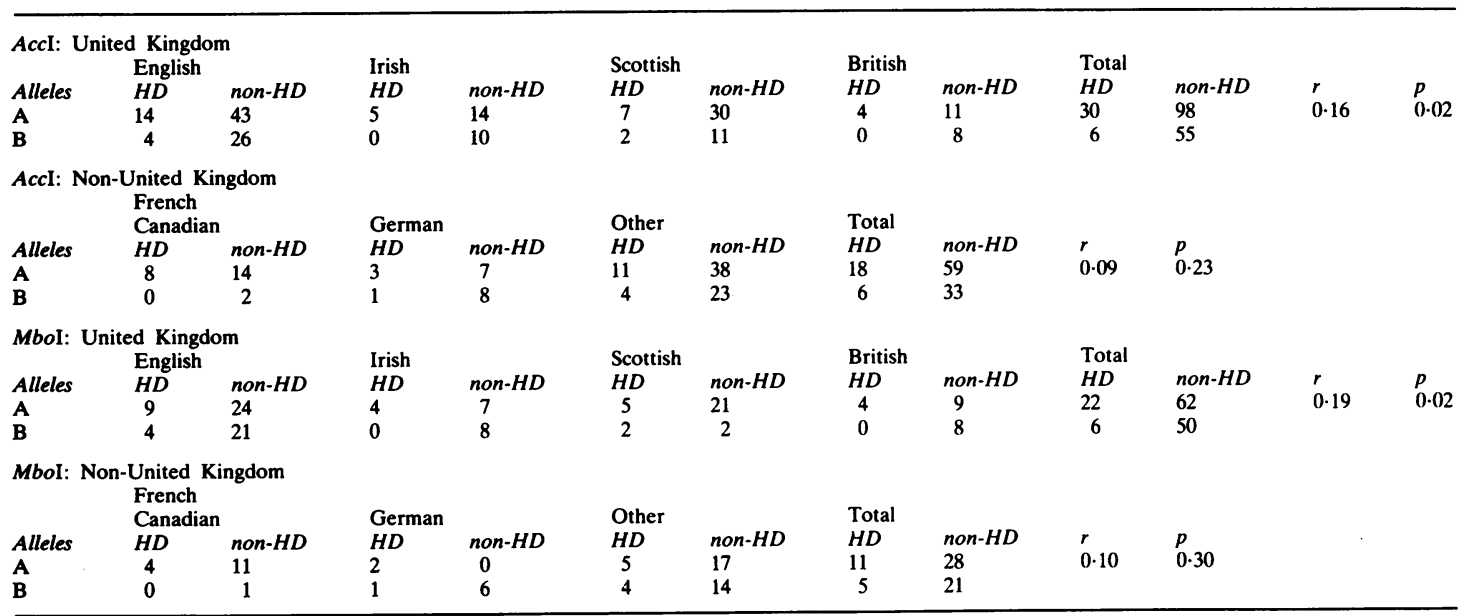



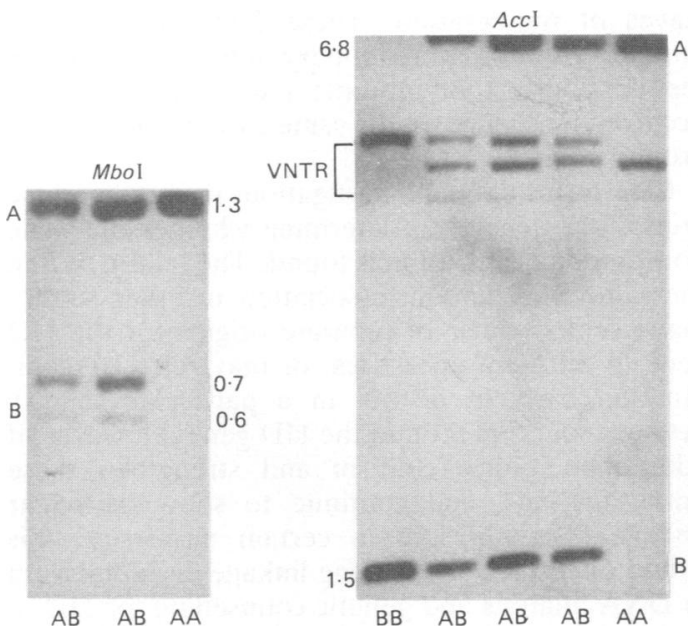

FIG 2 The polymorphisms of AccI and Mbol detected by $D 4 S 95$. A refers to the larger fragment $(6 \cdot 8,1 \cdot 3 \mathrm{~kb})$ while $B$ pertains to the smaller fragments $(0 \cdot 7,0.6 \mathrm{~kb})$.

TABLE 4 AccI and MboI haplotype frequencies in persons affected with $H D$ and their relatives.

\begin{tabular}{|c|c|c|c|c|c|c|}
\hline & \multicolumn{2}{|c|}{$\begin{array}{l}H D \\
\text { chromosome }\end{array}$} & \multicolumn{2}{|c|}{$\begin{array}{l}\text { Non-HD } \\
\text { chromosome }\end{array}$} & \multirow[t]{2}{*}{$r$} & \multirow[t]{2}{*}{$p$} \\
\hline & No & $\%$ & No & $\%$ & & \\
\hline A $(A c c \mathrm{I})$ A $(M b o l)$ & 39 & 76 & 91 & 55 & $0 \cdot 15$ & 0.01 \\
\hline $\mathrm{AB}$ & 0 & & 12 & 7 & & \\
\hline BA & 0 & & 1 & 1 & & \\
\hline BB & 12 & 24 & 62 & 37 & & \\
\hline Total & 51 & 100 & 166 & 100 & & \\
\hline
\end{tabular}

controls for the polymorphisms detected by $D 4 S 62$, $D 4 S 10, D 4 S 96$, and D4S141. However, two of the three RFLPs (AccI and $\mathrm{MboI}$ ) (fig 2) detected by D4S95 show statistically significant differences $(p=0.005$ and $p=0.007$, respectively) in allelic frequencies between HD chromosomes and controls. The third RFLP (TaqI) detected by D4S95 shows no allelic frequency difference between HD and nonHD chromosomes $(p=0 \cdot 35)$. The polymorphism detected by $D 4 S 98$ is also in linkage disequilibrium with HD $(\mathrm{p}=0.03)$.

The families in this study represent many different ancestries (table 1). A significant difference for $A c c I$ $(\mathrm{p}=0.02)$ and $M b o \mathrm{I}$ alleles $(\mathrm{p}=0.02)$ on HD and non-HD chromosomes was seen in families emanating from the United Kingdom. However, for the smaller number of families outside the UK the trend in allele frequencies was similar but was not statistically different (table 3 ).

As noted previously, ${ }^{3}$ the single site variation polymorphism detected by $A c c \mathrm{I}$ is in strong linkage disequilibrium with $M b o$ I. For these two RFLPs the $A$ alleles cosegregate as do the $B$ alleles. Thirty-nine of $51 \mathrm{HD}$ chromosomes have an AA haplotype and 12 have a BB haplotype. No AB or BA haplotypes were detected in this group (table 4). It was possible to determine the phase of the AccI and $M b o \mathrm{I}$ polymorphism segregating with HD in 67 and 51 of 75 families assessed respectively (table 4 ). There were significant differences in the haplotype frequencies between HD and non-HD chromosomes $(p=0.01)$ (table 4) and the families from the UK when analysed as a separate group $(p=0.02)$ (table 5).

TABLE 5 AccI and Mbol haplotypes of HD and non-HD chromosomes by ancestry.

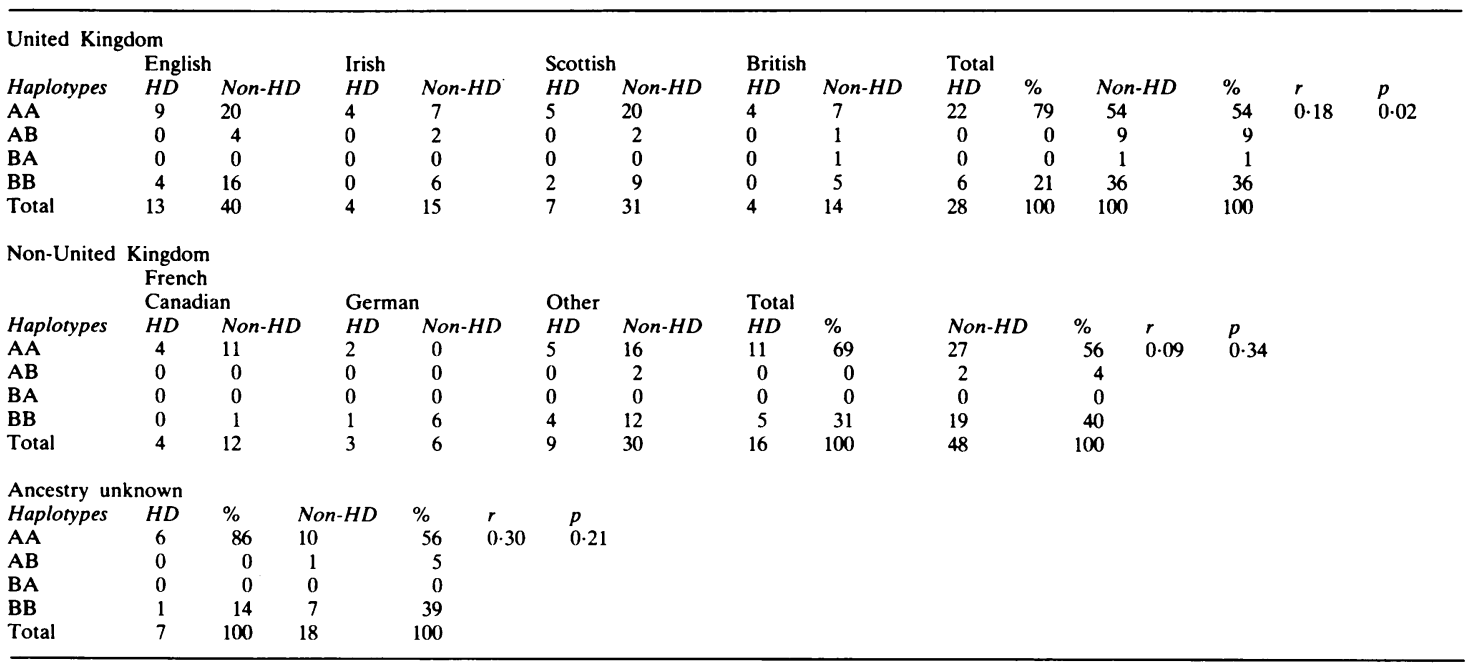


However, there is a similar trend but no significant difference in the haplotype distributions of HD and non-HD chromosomes for the families from outside the United Kingdom $(p=0.34)$ and for families with unknown ancestry $(p=0 \cdot 21)$ (table 5).

\section{Discussion}

The major finding of this study is the non-random association between alleles for $A c c I$ and $M b o I$ detected by $D 4 S 95, S s t I$ alleles for $D 4 S 98$, and the mutant gene for HD.

Linkage disequilibrium was detected with $\mathrm{MboI}$ and AccI and not with TaqI with D4S95. Possible explanations for this include the presence of a recombinational hot spot between the sites for TaqI on the one hand and $M b o \mathrm{I}$ and $A c c \mathrm{I}$ polymorphisms on the other. Alternatively it has already been shown that the recognition site for TaqI itself may act as a mutational hot spot $^{16}$ with the TaqI polymorphism arising independently on several occasions. Finally it is possible that there are multiple origins of the HD gene on identical $A c c \mathrm{I}$ and $\mathrm{MboI}$ haplotypes but different TaqI backgrounds. In all these instances linkage disequilibrium would not be apparent with TaqI.

The 75 families in this study are of many different ancestries with the majority being of British descent (41/75). The other 34 families include at least 15 different ancestries. The allele frequencies of $A c c \mathrm{I}$ and $M b o I$ show significant differences between HD and non-HD chromosomes for the whole group and for families from the United Kingdom. A similar trend, but which with smaller numbers does not show statistical significance, was seen with the non-UK families. It is particularly noteworthy that the haplotype distributions do not significantly differ between UK and non-UK families.

HD is a disease with an extremely low mutation rate. The frequency of the disease in persons of Caucasian descent varies between 5 and 7/100 000, while there is a particularly low prevalence in persons of Black and Japanese descent. ${ }^{17}$ These findings, together with accumulating genealogical evidence which traced families in Australia, ${ }^{18}$ South Africa, ${ }^{19}$ and North America ${ }^{20}$ to Europe, implicates north western Europe as the major source of the gene and suggests that there may have been only a few separate mutations underlying the frequency of $\mathrm{HD}$ in the world. ${ }^{17}$ The finding of similar haplotype distributions in both British families and other families of many different ancestries is suggestive evidence against many different mutations underlying HD. On the contrary this would suggest that there may be only a few HD mutations which have spread around the world during particular waves of immigration. These findings, however, must be viewed as preliminary and do not exclude the possibility that multiple mutations may have occurred by chance on the same chromosomal background.

Clearly, additional investigations in certain ethnic groups are needed to determine whether the same non-random association is found. The failure to find the same non-random association in other studies may occur because of separate origins for the HD gene in different ancestries, or may reflect recombination early in history in a particular country between markers around the HD gene. However, if additional studies confirm and strengthen these initial findings, and continue to show particular linkage disequilibrium in certain ancestries, this would open the way to using linkage disequilibrium in DNA analysis and genetic counselling for HD in certain situations. It may be possible to calculate high and low risk haplotypes.

Over $80 \%$ of persons requesting predictive testing for $\mathrm{HD}$ are able to receive a significant change in risk. ${ }^{21}$ Our major limitation in performing DNA analysis for such persons is the unavailability of DNA from crucial family members, which excludes up to $20 \%$ of persons from receiving a modification of risk. The ability to detect heterozygosity in an affected person is not now a problem if multiple highly polymorphic markers are used. ${ }^{21}$ Linkage disequilibrium data, if confirmed, may significantly reduce the need for DNA from numerous relatives and may allow predictive testing to be performed even in the absence of DNA from an affected person in certain instances. Such linkage disequilibrium data are now frequently used for risk calculation in some cystic fibrosis families where it has improved estimates of risk. ${ }^{22}$

These HD haplotype studies are similar to investigations in cystic fibrosis in that for both diseases the mutant gene is not cloned. In both instances linkage disequilibrium data can be used to provide clues as to the location of the mutant gene. ${ }^{23}$

In this study, non-random association was not seen with four other polymorphic DNA markers including D4S62, D4S10,D4S96, and D4S141. In particular no evidence for linkage disequilibrium was seen using distal markers D4S96 and D4S141. The absence of disequilibrium does not necessarily imply that it does not exist but rather that it was not detected. The sample sizes in this study are small compared with those that are absolutely necessary for a definite statement that disequilibrium does not exist.

Nevertheless some conclusions based on the data presented can be made. In particular, these findings suggest that the gene for HD may be more proxi- 
mally located than we, ${ }^{8}$ and others,${ }^{6}$ have previously reported and may be centromeric to some of the more distally located DNA markers such as $D 4 S 90$ or D4S141. A reasonable explanation for the apparent contradictory results concerning the location of the HD gene is that double recombination has occurred. Currently, in the absence of a polymorphic sequence adjacent to the telomere, this hypothesis remains untested. Nevertheless these findings suggest that directed cloning strategies to identify the gene for HD should not be concentrated only on the most distal region close to the telomere on chromosome 4 .

We wish to thank Drs J Gusella, M Singer, R Snell, D Shaw, and S Youngman for gifts of the probes. We wish to thank the following people for their cooperation with this study; Ms M Klimek, Dr O Suchowersky, Calgary; Dr S Grover, Dr S Bamforth, Edmonton; Mr B Lynch, Dr M Shokeir, Saskatoon; Ms L Thompson, Dr C Greenberg, Winnipeg; Dr H Soltan, London; Ms D Eisenberg, Hamilton; Ms S Bobkin-Raz, North York; Mr M Cook, Dr A Hunter, Ottawa; Ms J Fleming, Dr P MacLeod, Dr P Bridges, Kingston; Dr P Welch, Ms A Fuller, Halifax; Dr E Ives, St John's, Canada. This study has been supported by grants from the MRC (MA9131) (MRH), The National Health Research Development Program, a Western Canadian private foundation, and NIH grants GM40864 (JCM, KHB) and GM07091 (RS). Oliver Quarrell is supported by the Royal Society (UK) and NSERC. Bernhard Weber is supported by a Fellowship from the Deutsche Forschungsgemeinschaft (We 1259/1-1) and Colin Collins is a predoctoral scholar of the Huntington Society of Canada.

\section{References}

${ }^{1}$ Gusella JF, Wexler NS, Conneally PM, et al. A polymorphic DNA marker genetically linked to Huntington disease. Nature 1983;306:234-9.

2 Hayden MR, Hewitt J, Wasmuth JJ, et al. A polymorphic DNA marker that represents a conserved expressed sequence in the region of the Huntington's disease gene. Am J Hum Genet 1988;42:125-31.

3 Wasmuth JJ. Hewitt J, Smith B, et al. A highly polymorphic locus very tightly linked to the Huntington's discase gene. Nature 1988:332:734-6.

4 Youngman S, Shaw DJ, Gusella JF. et al. A DNA probe (D4S90) mapping to human chromosome 4p16.3. Nucleic Acids Res 1988:16:1648.

5 Gilliam CG. Tanzi RE, Haines JL. et al. Localization of the Huntington's discase gene to a small segment of chromosome 4 flanked by D4S10 and the telomere. Cell 1987:50:565-1.
6 Whaley WH, Michiels F. MacDonald ME, et al. Mapping of D4S95/S114/S113 confines the Huntington's defect to a reduced physical region at the telomere of chromosome 4. Nucleic Acids Res 1988;16:11769-80.

7 Bates G, Baxendale S, Sedlacek Z, et al. A telomere clone likely to contain the mutant form of the Huntington's disease locus. Human Gene Mapping 10, 1989, A2354. Cytogenet Cell Genet (in press)

${ }^{8}$ Robbins C. Theilmann J, Youngman S, et al. Evidence from family studies that the gene causing Huntington disease is telomeric to D4S95 and D4S90. Am J Hum Genet 1989;44: 422-5.

${ }^{9}$ MacDonald ME, Haines JL, Zimmer M, et al. Recombination events suggest potential sites for the Huntington's disease gene. Neuron (in press).

${ }^{10}$ Nakamura Y, Lathrop M, O'Connell P, et al. Frequent recombination is observed in the distal end of the long arm of chromosome 14. Genomics 1989;4:76-81.

1 Southern E. Detection of specific sequences among DNA fragments separated by gel electrophoresis. J Mol Biol 1975;98:50317.

12 Feinberg AP, Vogelstein B. A technique for labelling DNA restriction endonuclease fragments to high specific activity. Anal Biochem 1983;132:6-13.

13 Hayden MR, Kirk H. Clark C, et al. DNA polymorphisms in and around the Apo-AI-CIII genes and genetic hyperlipidemias. Am J Hum Genet 1987;40:421-30.

14 Smith B, Skarecky D, Bengtsson U, Magenis RE, Carpenter N, Wasmuth JJ. Isolation of DNA markers in the direction of the Huntington disease gene from the G8 locus. Am J Hum Genet 1988;42:335-44.

15 Snell RG, Youngman S. Lehrach H, Sarfarazi M, Harper PS, Shaw DJ. A new probe (2R3) in the region of Huntington's disease. Human Gene Mapping 10, 1989, A2621. Cytogenet Cell Genet (in press).

${ }^{16}$ Barker D, Schafer M, White R. Restriction sites containing Cpt show a higher frequency of polymorphism in human DNA. Cell 1984;36:131-8.

17 Hayden MR. Huntington's chorea. New York, Berlin: Springer Verlag, 1981.

${ }^{18}$ Brothers CR. Huntington's chorea in Victoria and Tasmania. J Neurol Sci 1964:1:405-20.

19 Hayden MR. Hopkins HC, Macrae M, Beighton P. The origins of Huntington's chorea in the Afrikaner population of South Africa. $S$ Afr Med J 1980;58:197-200.

20 Barbeau A. Fulham G. Origin and migration of Huntington's chorea in Canada. Preliminary report. Can Med Assoc J 1952:87:1242-3.

2 Hayden MR, Robbins C, Allard D, et al. Improved predictive testing for Huntington disease using three linked DNA markers. Am J Hum Genet 1988;43:689-94.

22 Beaudet AL, Feldman GL. Fernbach SD, Buffone GJ, O'Brien WE. Linkage disequilibrium, cystic fibrosis and genetic counselling. Am J Hum Genet 1989:44:319-26.

${ }^{23}$ Murray JC. Buetow KH, Donovan M, et al. Linkage disequilibrium of plasminogen polymorphisms and assignment of the gene to human chromosome 6q26-6q27. Am J Hum Genet 1987:40:338-50.

Correspondence to $\mathrm{Dr}$ Michael $\mathrm{R}$ Hayden, Department of Medical Genetics, F168 University Hospital, 2211 Wesbrook Mall, Vancouver, BC V6T 2B5, Canada. 